\title{
Pre-purchase Agreement on the Covid-19 Vaccine and its Impact on the Right to Health
}

\author{
Josina Augustina Yvonne Wattimena ${ }^{1 *}$, Mariah Agnes Matakena ${ }^{2}$ \\ 1, 2, Faculty of Law Pattimura University, Ambon, Indonesia \\ *E-mail: josinaaywattimena@gmail.com
}

\begin{tabular}{l}
\hline Article Info \\
\hline Keywords: \\
Pre-Purchase \\
Agreement; Vaccine \\
Covid-19; Global \\
Public Health; \\
Developing Nations. \\
\\
\\
DOI: \\
10.47268/sasi.v27i4.681 \\
\hline
\end{tabular}

\begin{abstract}
A vaccine is a core solution to decreasing the widespread damage caused by the COVID-19 pandemic. However, the race to find a vaccine requires a large budget to finance research and development carried out by pharmaceutical companies. This funding is usually accommodated by wealthy developed nations who enter per-purchase agreements with these companies that guarantee a large quantity of the approved vaccines, honored in the agreements between these countries and the pharmaceutical companies. However this agreement blocks the access to other countries, especially developing countries to purchase the same vaccines therefore unable to fulfill their citizens' right to health as regulated in the universal declaration of human rights and other international legal sources. In analyzing this, the method of research used is a legal normative approach by studying literary materials, international legal documents, and case studies. The conclusion of this research is that pre-purchase agreements are a right of developed nations to fulfill the right of their citizens on one perspective however on the other it violates the right of the international community, especially small and developing countries to fulfill their right to health.
\end{abstract}

\section{A. INTRODUCTION}

The Covid-19 pandemic on global economic developments has an influence not only on the world of economy and investment ${ }^{1}$. The era of globalization and free markets is increasingly growing and challenging the boundaries of states which have been claimed. Competition is one of the characteristics of the free market that requires countries to compete. This was no exception during the Covid-19 pandemic, where developed and financially strong countries demonstrated their ability to tackle Covid-19 by investing their shares in large and reputable pharmaceutical companies to obtain vaccines.

The spread of the virus across national borders forces the international community to suppress the spread of the virus with great struggle as it is feared to continue. It this endeavor, countries have been searching for solutions that are guaranteed to reduce the effects of the

1 Saija, R., \& Sudiarawan, K. A. (2021). Perlindungan Hukum Bagi Perusahaan Debitur Pailit dalam Menghadapi Pandemi Covid 19. Batulis Civil Law Review, 2(1), 66-77. 
pandemic, because the consequences of this pandemic condition has weakened almost all areas of life such as politics, economy, social, education, culture and health globally. Due to this, vaccines are pursued for the sake of restoring the health of the international community, yet the problem is it takes a lot of time and effort result in successful vaccines. Vaccines are made and produced by pharmaceutical companies around the world, and they are racing to provide a solution to this global health crisis. In fact, the strong and developed countries have invested billions of funds into big pharmaceutical companies to develop candidate vaccines as reported by various media. Europe's largest pharmaceutical company AstraZeneca made an agreement with the Vaccines Alliance, which was formed by France, Germany, Italy and the Netherlands to accelerate the production of a vaccine. In fact, the company has already made deals with the UK and the US. ${ }^{2}$ In addition to the pharmaceutical companies mentioned above, the United States, for example, is known to have bought up supplies of 100 million candidates for the Covid-19 vaccine from pharmaceutical companies BioNTech and Pfizer. The United Kingdom and the European Union (EU) also secure stocks of candidate vaccines from GlaxoSmithKline, Sanofi, AstraZeneca and Moderna. ${ }^{3}$ When these candidate vaccines are ready to be released to the public, the countries that have signed the contracts that pay a part of the initial cost of production of the candidate vaccines, will be the ones that are entitled to obtain the vaccines first. The agreements made by countries with these pharmaceutical companies are known as Pre-Purchase Agreements for the Covid-19 Vaccine.

The reality of this is that it contradicts the regulation of international human rights law, especially in article 25 of the Universal Declaration of Human Rights which explicitly states; everyone has the right to a standard of living adequate for the health and well-being of himself and of his family, including food, clothing, housing and medical care and necessary social services, and the right to security in the event of unemployment, sickness, disability, widowhood, old age or other lack of livelihood in circumstances beyond his control. ${ }^{4}$

The right to health as regulated in the Universal Declaration of Human Rights emphasizes the existence of the right to health including the right to specific health issues including infectious diseases. Article 12 of the ICESCR imposes an authoritative obligation on States to take appropriate steps to fulfill the right to health. ${ }^{5}$ Due to this, the reality of the efforts made by developed countries taking a step to answer the need for vaccines for their citizens is an action that cannot be blamed as the obligation to fulfill the right to health lies with the State. The problem is that the pre-purchase agreement carried out by developed countries is a monopoly action which then limits the right to health of everyone to enjoy health and welfare for themselves and their family. This monopolistic action by developed countries towards candidate vaccines through investment of funds is considered a very fundamental measure of restricting the right to life of other individuals.

In the Universal Declaration of Human Rights (UDHR), Article 2 states "Everyone has the right to all the rights and freedoms set forth in this Declaration with no exceptions whatsoever, such as discrimination of race, color, sex, language, etc. religion, politics or other views, national or social origin, property rights, birth or other positions. Furthermore, there will be no differentiation on the basis of the political, legal or international position of the country or region from which a person originates, whether from an independent country, in the form of guardianship, colony or those under other sovereign boundaries". The actions of these

\footnotetext{
https:/www.voaindonesia.com/a/astrazeneca-teken-kesepakatan-vaksin-corona-dengan-sejumlahnegara-eropa/5461697.html, accessed 29 October 2020

3 https://health.detik.com/berita-detikhealth/d-5113898/negara-kaya-berlomba-borong-vaksin-coronabagaimana-nasib-dunia, accessed 29 October 2020

${ }^{4}$ United Nations, , Human Rights and Compilation of International Instrumen Vol 1( first part) (New York : United nation, 2002, p. 5, quoted from Muhtaj, M. E. (2008). Dimensi-Dimensi HAM Mengurai Hak Ekonomi. Sosial, dan Budaya, Jakarta: RajaGrafindo Persada, p. 153

5 Ibid, p. 154

415|SASI Volume 27 Issue 4, October - December 2021
} 
developed countries can not only be considered a limitation of the right to life, but also as a form of injustice towards the access to health.

\section{B. RESEARCH METHODS}

The research method used in writing this paper is normative juridical research that is qualitative and comparative. The normative juridical method is used in this study is to analyze the sources of legal materials that refer to the norms contained in statutory regulations. This normative juridical method also refers to research that leads to the philosophical basis of the pre purchase agreement with the philosophy of the agreement principles used to dissect the issues raised.

\section{RESULTS AND DISCUSSION}

\section{The Existence of Agreement Principles in Law}

Nowadays, agreements are a means of communicating various interests and cooperation that is used as a very important source of law. In the international legal system, treaties as a form of agreement are always placed as the main source of law ${ }^{6}$. Many international relations between states are outlined in the instruments of international agreement (treaty). Through these international treaties they formulate rights and obligations ${ }^{7}$. The increasing interdependence between countries encourages international cooperation, which in many cases is formulated in the form of international agreements. The existence of differences in state systems, state forms, and different views of life, culture, religion or belief is not an obstacle to establishing cooperation, in some cases it can even increase the intensity of relations between countries ${ }^{8}$.

For the implementation of international agreements between countries is always protected under some principles of international law such as Free consent, Good Faith, Pacta sunt servanda, Rebus Sic Stantibus and others. The principles mentioned in international law are very fundamental. Therefore, in article 38 paragraph (1) of the International Court of Justice, the general principles of this law are a very important source of law. Fundamental and basic principles in international law are thus positioned as Jus Cogens, because they are recognized by civilized nations ${ }^{9}$. Rozakis contradicts the meaning of the Jus Cogens as a general international legal norm that has been accepted and recognized by the international community as a whole and has been applied to almost all countries because it is binding. ${ }^{10}$.

Not contradicting the theories from previous experts, Akehurst discovers that a rule in international law cannot be jus cogens if it was not accepted and recognized by the international community as a whole. Thus the practice of countries that are consider local customs in relation to Jus Cogens, can be valued to a higher degree if accepted by the international community. ${ }^{11}$

The meaning of the principle according to the General Indonesian Dictionary has three meanings, namely: a) Base, foundation or guidelines; b) A truth that becomes the foundation of

\footnotetext{
6 Article 38 paragraph 1 of the Statute of the International Court of Justice places international treaties first as a source of international law. This means that when the International Court of Justice has to resolve the cases it faces, it will first look at whether or not there is a binding agreement for the parties to the dispute.

7 Treaty is a general term for referring to International Agreements. Other terms for referring to international agreements are convention, agreement, arrangement, Protocol, Vivendi Mode, and so on. The use of terms in making international treaties depends on the agreement of the States parties, the 1969 Vienna Convention as a source of law for making international treaties does not oblige international treaty makers to use certain terms.

8 Purwanto, H. (2009). Keberadaan asas Pacta Sunt Servanda dalam perjanjian internasional. Mimbar Hukum, 21(1), 155-170.

9 Mochtar, K., \& Agoes, E. R. (2003). Pengantar Hukum Internasional. Bandung: Alumni. p. 15.

${ }^{10}$ Rozakis, C. L. (1976). The Concept of Jus Cogens In The Law of Treaties. Amsterdam; New York: NorthHolland Publishing Company; New York: sole distributors for the USA, Elsevier/North-Holland. quoted from Yudha Bakti, Pajajaran Magazine No. 1 1981, p. 55.

${ }^{11}$ Akehurst, M. (1979). A Modern To Inernastional law, London: George Allen and Unwin, LTD, p. 46.

416|S ASI Volume 27 Issue 4, October - December 2021
} 
thinking, c) The ideals that become a base of thought. From this definition it can be concluded that a principle is the basis or place of thinking lies in obtaining truth. According to Paton, a principle is a form of thought that is broadly formulated and underlies the existence of a legal norm. Based on Paton's opinion, it can be said that the existence of a legal norm is based on principles hence that every legal norm must be linked back to its principles. A similar opinion was expressed by van Erkema Hommes, that legal principles should not be regarded as concrete legal norms, however as a general basis or guidelines for law. The formation of practical law needs to be oriented towards these legal principles ${ }^{12}$.

Another opinion regarding legal principles as stated by Ron Jue, is that legal principles are the values that underlie legal principles. ${ }^{13}$ Based on the description above, it can be said that the principle of law is a realm of thought or ideals behind the formation of legal rules, both general and abstract and universal, not concrete. ${ }^{14}$ In fact, Scholten states that the principle of law is either in the legal system or behind or outside the legal system. As long as the value of the legal principle is manifested in the legal principles of the positive legal system, the legal principle is in the system. On the contrary, as long as the value of the legal principle is not manifested in the legal principles of the positive legal system, then the legal principle is behind the legal system. ${ }^{15}$ Legal principles can be interpreted as something that is considered by the legal community concerned as basic truth, because it is through legal principles that ethical and social considerations of the community enter into law ${ }^{16}$.

The use of these principles in common law proved its diverse application in all fields of law. This indicates that these legal principles conform to or are the same as universal legal principles and their applicability is not limited to space, time and place. This shows that the principles of law can apply to all legal systems. Such as the principle or right to freedom of contract and good faith, which are principles that apply to both the international legal system and national law.

The freedom of contract principle is known as partij autonomie" or liberty of contract. The freedom of contract principle is a universal principle, meaning that it is adhered to by contract law in all countries. ${ }^{17}$ The freedom of contract principle is a universal principle, Schmitthoff in 'Huala Adolf' emphasized that "The autonomy of the parties will in the law of contract is the foundation on which an autonomous law of international trade can be built. The national sovereign has, no objection that in that area an autonomous law of international trade is develop by the parties, provided always that the law respect in every national jurisdiction the limitations imposed by public policy ${ }^{18}$.

Based on this principle, it is the right of everyone whether or not to make an agreement. The parties who have agreed to make a free agreement determines what can and should not be included in an agreement. The application of this principle provides an important plpatform for the application of the principle of consent, which indicates a balance of interests, a balance in risk sharing, and a balance in bargaining position. Freedom to contract is a principle that was born in the era of the laisseiz faire which in the economic field was pioneered by Adam Smith,

12 Mertokusumo,S. (2001). Penemuan Hukum, Yogyakarta: Liberty, P. 5.

13 Ibid.

14 General law principles refer to the application of these principles in all areas of law. Meanwhile, the principle of universal law refers to the application of these principles anytime and anywhere, regardless of time and place. Scholten shows that there is a special legal principle, namely the principle of law that applies to one area of law only. Sudikno Mertokusumo, Loc. cit., p. 6.

15 Ibid

16 Solikha, N. M. (2015). Asas Itikad Baik Sebagai Pembatas Kebebasan Berkontrak Dalam Perjanjian Kredit Bank, (Tesis: UII, Yogyakarta) p. 46

17 Sairam Bath, 2009, loc. Cit., P. 9, Willem M Vissert Hooft, 2005, loc. Cit, Mo Zhang, Chinese Contract Law, 20061 Loc. Cit, quoted from Priyono, E. A. (2017), Peranan Asas Iktikad Baik Dalam Kontrak Baku (Upaya Menjaga Keseimbangan Bagi Para Pihak), Diponegoro Private Law Review 1(1)

18 Ibid. p. 17.

417|SASI Volume 27 Issue 4, October - December 2021 
in order to prevent excessive government interference, and a form of individualism ${ }^{19}$.

In its development, this principle appears to as a new paradigm in contract law that leads to unrestricted freedom of contract. ${ }^{20}$ This principle also enables strong parties to impose their will on weak parties, so that the ideals of freedom of contract which initially provides legal balance, balance of interests and also balance in bargaining positions experiences a shift in value.

Furthermore, a principle that is closely related to the issues aforementioned is the principle of good faith. All agreements must be carried out in good faith (te goeder trouw). If this principle of good faith is juxtaposed with the content of Article 1338 paragraph 3 of the Civil Code (KUH Perdata), this principle confirms that the parties in making agreements must be based on good faith and propriety, which implies that the making of an agreement between the parties must be based on honesty to achieve common goals. The implementation of the agreement must also refer to what should and should be followed in public relations. This principle is must be present in every agreement.

The principles of good faith and compliance come from Roman law, which was later adopted by civil law, and even in its development it was also adopted by several Common Law countries. $^{21}$ The development of good faith in Roman law cannot be separated from the evolution of contract law itself. In good faith at the pre-contracting stage, it can be explained that if the implementation of a contract creates imbalance or violates feelings of justice, the judge can make adjustments to the rights and obligations stated in the contract. Therefore, if referring to the article 1337 in the Civil code (KUH Perdata), there are limits imposed on the practical application of this principle by affirming the "cause" of the agreement to be lawful and not prohibited by the laws or not contrary to good morals or public order. In general, the understanding of the definition of "good faith" consists of two definitions ${ }^{22}$ : a) The objective meaning: that the agreement made must be carried out by heeding the norms of decency and morality, b) The subjective meaning: namely the meaning of "good faith" which lies in one's inner attitude. Substantially, both freedom of contract and good faith are important pillars in the contract law. Furthermore, these two principals will be analyzed in their application in relation to the problem of the covid-19 vaccine pre- purchase agreement.

\section{The Norms of Right to Health}

Article 1 of the Universal Declaration of Human Rights (UDHR) states that "all men are born free and have the dignity and rights of the same; they are endowed with reason and conscience and should associate with one another in brotherhood". The standard of human rights norms in article 1 of the UDHR positions the universality of human dignity and the basic rights that underlie it, which cannot be denied by anyone. The reality exists that in order to develop one's dignity as a human being with a number of rights he has, it is inevitable that other people are needed for and to provide guarantees, protection and fulfillment of these rights.

The spirit of brotherhood has become an echo that has been echoed since human rights were fought for through the French revolution with the slogan liberte, (freedom); egalite (equality; justice); and fratenite (brotherhood). The spirit of brotherhood is a "moral right" that has a great positive message in seeing and treating others in the spirit of "I am him and he is me "and "they are us and we are them". This commitment and spirit of brotherhood has actually

19 Ridwan, K. (2004). Itikad Baik Dalam Kebebasan Berkontrak. Jakarta: Indonesian University Graduate School of Law. P. 42

20 Ibid.

21 Ian Ayrest and Robert Gertner, Filling Gap in Incomplet Contract: an Economic Theory of Default Rules in Eric A Posner, 2001, Law and Economics Second Series, Burlington, USA, Ashgate Dartmouth, p. 1 quoted from Priyono, E. A. Op. Cit. p. 19.

${ }^{22}$ Syaifuddin, M. (2012). Contract Law: Understanding Contracts in Perspective Philosophy, Theory, Dogmatics and Legal Practice. Bandung: Mandar Maju., p. 95

418|S ASI Volume 27 Issue 4, October - December 2021 
been normatively stated in Article 7 "All human rights are universal, indivisible, interdependent and interrelated; All human rights and fundamental freedoms in this Declaration shall be treated fairly and equally, on an equal footing and with the same emphasis". Therefore, the principles formulated in human rights such as equality, non-discrimination and state obligations aim to implement human rights in the spirit of universality without being limited by the various interests that surround it.

The concept of the right to health as a human right and as a necessary condition for the fulfillment of other rights has been recognized internationally. The right to health includes the right to get a healthy life and work and the right to get health services.

Article 25 of the Universal Declaration of Human Rights (UDHR ) states: Every person has the right to a standard of living adequate for the health and well-being of himself and his family, including the right to food, clothing, housing and health services, necessary social services, and the right to security at the time of unemployment, illness, disability, abandonment by a partner, elderly people, or other conditions that result in a decline in the standard of living that occurs outside of his control ${ }^{23}$.The guarantee of the right to health is also contained in Article 12 paragraph (1) of the International Convention on Economic, Social and Cultural Rights adopted by the United Nations General Assembly 2200 A (XXI) on December 16, 1966. It states that members of the convention recognize the right of every person to enjoy the highest attainable standards of physical and mental health.

In observing the development of human rights, norms cannot be separated from the essence of the human rights generations, which Karel Vasak developed from the theme of human rights that occurred through the French revolution's: liberte, egalite and fraternite ${ }^{24}$. Vasak explained that the sense of the first generation of human rights is freedom (liberte), which is fundamentally civil and political in nature, and aims to protect everyone from oppression by state authorities, such as freedom of speech /opinion, freedom of religion, suffrage, and the right to be tried in an honest manner (fair trial). ${ }^{25}$ Second generation of human rights are related to equality (egalite) in the social and economic fields. Human rights of the second generation, calls for the same economic and social treatment among all the citizens. The rights related to this include the right to work, the right to housing and the right to health, including social security. The third generation of human rights is a development of social and economic rights. The idea that underlies the third generation of human rights is how to implement real human rights for the improvement of human life. Human rights must be able to close the gap between developed countries and developing countries. The similarity between large and small countries in international law must be reflected in practice, because the principle of equality (egalite) which applies to the relations between individuals must also apply in relations between countries. The interests of certain worthy classed as a right in the sense that the truth, whatever that may mean by that. ${ }^{26}$

There is a possibility that human rights, will become broader. This is in line with what Scott Davidson has stated, that the notion of human rights itself is not static but dynamic, so that there is probably a lot of debate about whether certain interests deserve to be classified as

23 https://reference.elsam.or.id/wp-content/uploads/2014/12/KESEHATAN-SEBAGAI-HAK-ASASIMANUSIA.pdf, accessed 2 Nov 2020

${ }^{24}$ Karel Vasak, "Human Rights: A Thirty-Year Struggle: the Sustained Efforts to give Force of law to the Universal Declaration of Human Rights", UNESCO Courier 30:11, P aris, November 1977, quoted as https: // Reference.elsam.or.id/wp-content/uploads/2014/12/K Kesehatan_Sebagai_Hak_Asasi_Manusia.pdf, accessed on 2 November 2020

25 Ibid

26 Karel Vasak, "Human Rights: A Thirty-Year Struggle: the Sustained Efforts to give Force of law to the Universal Declaration of Human Rights", UNESCO Courier 30:11, P aris, November 1977, quoted as https: // Reference.elsam.or.id/wp-content/uploads/2014/12/K Kesehatan_Sebagai_Hak_Asasi_Manusia.pdf, accessed on 2 November 2020

419|SASI Volume 27 Issue 4, October - December 2021 
rights in the true sense, however it is defined. ${ }^{27}$

In relation to the right to health, there are two aspects. First, the health aspect as an individual right which gives birth to the government's obligation to fulfill it. Second, the public health aspect. Health as an individual right has not received general recognition and is still derogable. Developing countries in particular still have difficulty accepting the right to health as an individual right for various reasons. Apart from that it will require expensive investment but also that factors that determine an individual's health extend far beyond the health factor itself.

\section{Analysis: Pre Purchase Agreement Covid 19 Vaccine and Its Impact on the Right to Health}

Since the COVID-19 pandemic broke out in China and then spread in various parts of the world, the total number of cases infected with COVID-19 worldwide has reached 48,171,563, and the number of cases continues to increase worldwide, both countries individually or in cooperation under the control of WHO have taken action in response. The government's efforts to maintain public safety and maintain economic stability, in the spread of COVID-1928.

Developed nations like USA, UK, Australia, and other countries have invested large amounts of funds to pharmaceutical companies that develop COVID-19 vaccines in exchange for a guaranteed number of vaccines once approved to be produced. For example, the United States government has invested US \$1.2 billion in the Astrazeneca vaccine named AZD1222 for 300 million doses, as well as the candidate vaccine by BioNTech and Pfizer for US \$1.95 billion with a pledge of 100 million doses with options of up to 500 million more doses. Similarly, Australia has also pledged $\$ 1.5$ billion dollars for the development of a candidate vaccine by companies Pfizer and Novavax to obtain up to 134 million doses of vaccine. This is also the pattern played by other countries such as Canada, the US and the UK, which have secured at least five guaranteed vaccine supply deals. These deals are often based on many different terms such as prepayment agreements, advanced market agreements or even prepurchase agreements but they all more or less correspond to the same definition. Under the outline of a European commission contract to support the vaccine proposed by AstraZeneca, a pre-purchase agreement is an agreement in which the European Commission will finance a portion of the vaccine development and trial in advance as an advance payment to be purchased by member countries. The agreement is to accelerate the development and deployment of safe and effective vaccines to reward and goal right to buy a certain number of doses of vaccine within a certain period.

The agreement in a state of the Covid-19 outbreak greatly affects the implementation of the agreement stipulated and agreed upon by the parties ${ }^{29}$. If referring to the principle of freedom of contract, this is the right of every country to freely enter into contracts with anyone. Especially in these conditions, it is an obligation of each country to perform and take a step that is best for its citizens. Considering that the basic philosophy of the right to health as a human rights is the raison d'etre of human dignity, ${ }^{30}$ therefore, the basis of the right to health will always be closely correlated with how to guarantee protection and fulfillment of these rights. On the other hand, the issue of the right to health is not purely independent; it is always influenced by other factors such as what happened during the current Covid 19 pandemic. In

27 Davidson, S. (1994). Human Rights, History, Theory and Practices in International Relations, Grafity, p. 1 accessed on 2 Nov 2020

28 Taun, T., \& Nugraha, A. (2020). Penerapan Hukum dalam Pemutusan Hubungan Kerja dan Kebijakan Bank Terhadap Debitur yang Terdampak Pandemi Covid-19. Batulis Civil Law Review, 1(1), 24-32.

${ }^{29}$ Kunarso, K., \& Sumaryanto, A. D. (2020). Eksistensi Perjanjian Ditengah Pandemi Covid-19. Batulis Civil Law Review, 1(1), 33-46.

$30 \mathrm{https}$ ://www.voaindonesia.com/a/astrazeneca-teken-keskes-vaksin-corona-dengan-sejotal-negaraeropa/5461697.html, accessed October 29, 2020.

420|SASI Volume 27 Issue 4, October - December 2021 
this condition, political, economic, legal and other dimensions have a significant influence on these rights. The principle of freedom of contract plus the ability of developed countries from a financial and economic perspective with strong political bargaining power puts their position at a higher level.

The application of this principle places a balance of interests, a balance in the distribution of risk burdens, and a balance in the bargaining position. With the increasing needs and interests of humans, this principle appears to be a new paradigm in contract law that leads to unrestricted freedom of contract. ${ }^{31}$ Currently, pre purchase agreements as a legal instrument which puts prioritizes the truth of the act and sets aside the right enjoy the right to enjoy health altogether as mankind. The critical question that then arises is how can poor and underdeveloped countries get the right to defend their life in the midst of a situation of their country's powerlessness to fulfill their obligations. In this case, the principle of freedom of contract in its implementation cannot be separated from the principle of good faith, as both are one package. This evident the development of contract law. The attitude of good faith at the pre-contractual stage, which has been seen to imbalance or violate humanity's sense of justice, should be considered. In international law, the principle of good faith is a very fundamental principle in the implementation of agreements. This principle of good faith is what fosters security and peace.

The exclusivity of the pre purchase agreements made by most developed countries, who can afford to invest large sums of money, has raised concerns about how vaccines will be distributed. Even this agreement is against good faith as a means of achieving peace. This is due to the fact that the pre-purchase agreements between the of dominant countries like the US and the European Commission to secure a large number of candidate vaccines from various companies, results in a lack of opportunity for small countries that cannot afford to enjoy the vaccine. This certainly creates a feeling of being treated unfairly. The impact of these prepurchase agreements would severely hamper the smaller developing countries such as developing countries in the Pacific or Africa, unless they can cooperate with pharmaceutical companies like other developing countries such as Indonesia and Brazil with Pfzier Sinovac and BioNTech. Concern about the implementation of the nationalistic pre-purchase agreement from strong and developed countries in accessing the covid 19 vaccine will be very risky to global health, because fair access to vaccines is not strategically distributed to high-risk populations around the world but is also a violation of rights health of developing countries. The broader implication is that if the pre-purchase agreement is implemented it will weaken all aspects of life globally, be it political, economic, social, and others, because naturally there is no single country that does not depend on each other and cooperate.

\section{CONCLUSION}

Based on the explanation above, there are several conclusions that can be made: The pre purchase agreements for the Covid-19 vaccines conducted by financially strong and advanced countries - economically is the right of these countries as a form of fulfillment of the State's obligations for the health of their citizens, but this right should not be used to limit the rights of small and developing countries who cannot afford to enjoy their right to the vaccine. The impact of the implementation of the pre-purchase agreement has two aspects of providing health care for its citizens but also denying the global community the right to health, right to life, the right as a human being who is dignified and having welfare, contrary to the values of justice, complacency, and decency formulated in various international human rights instruments.

31 https://health.detik.com/berita-detikhealth/d-5113898/negara-kaya-berlomba-borong-vaksin-coronabimana-nasib-dunia , accessed 29 October 2020

421|SASI Volume 27 Issue 4, October - December 2021 


\section{REFERENCES}

\section{Journal}

[1] Kunarso, K., \& Sumaryanto, A. D. (2020). Eksistensi Perjanjian Ditengah Pandemi Covid19. Batulis Civil Law Review, 1(1), 33-46.

[2] Priyono, E. A. (2017), Peranan Asas Iktikad Baik Dalam Kontrak Baku (Upaya Menjaga Keseimbangan Bagi Para Pihak), Diponegoro Private Law Review 1(1).

[3] Purwanto, H. (2009). Keberadaan asas Pacta Sunt Servanda dalam perjanjian internasional. Mimbar Hukum, 21(1), 155-170.

[4] Saija, R., \& Sudiarawan, K. A. (2021). Perlindungan Hukum Bagi Perusahaan Debitur Pailit dalam Menghadapi Pandemi Covid 19. Batulis Civil Law Review, 2(1), 66-77.

[5] Taun, T., \& Nugraha, A. (2020). Penerapan Hukum dalam Pemutusan Hubungan Kerja dan Kebijakan Bank Terhadap Debitur yang Terdampak Pandemi Covid-19. Batulis Civil Law Review, 1(1), 24-32.

\section{Books}

[6] Akehurst, M. (1979). A Modern To Inernastional law, London: George Allen and Unwin, LTD.

[7] Davidson, S. (1994). Human Rights, History, Theory and Practices in International Relations, Grafity.

[8] Mertokusumo,S. (2001). Penemuan Hukum, Yogyakarta: Liberty.

[9] Mochtar, K., \& Agoes, E. R. (2003). Pengantar Hukum Internasional. Bandung: Alumni.

[10] Muhtaj, M. E. (2008). Dimensi-Dimensi HAM Mengurai Hak Ekonomi. Sosial, dan Budaya, Jakarta: RajaGrafindo Persada.

[11]Ridwan, K. (2004). Itikad Baik Dalam Kebebasan Berkontrak. Jakarta: Indonesian University Graduate School of Law.

[12] Rozakis, C. L. (1976). The Concept of Jus Cogens In The Law of Treaties. Amsterdam; New York: North-Holland Publishing Company; New York: sole distributors for the USA, Elsevier/North-Holland. quoted from Yudha Bakti, Pajajaran Magazine No. 11981.

[13] Syaifuddin, M. (2012). Contract Law: Understanding Contracts in Perspective Philosophy, Theory, Dogmatics and Legal Practice. Bandung: Mandar Maju.

\section{Online/World Wide Web, Thesis etc}

[14] https://www.voaindonesia.com/a/astrazeneca-teken-kesepakatan-vaksin-corona-dengansejumlah-negara-eropa/5461697.html.

[15]https://health.detik.com/berita-detikhealth/d-5113898/negara-kaya-berlomba-borongvaksin-corona-bagaimana-nasib-dunia.

[16] https://reference.elsam.or.id/wp-content/uploads/2014/12/KESEHATAN-SEBAGAIHAK-ASASI-MANUSIA.pdf.

[17] https://www.voaindonesia.com/a/astrazeneca-teken-keskes-vaksin-corona-dengan-sejotalnegara-eropa/5461697.html.

[18]https://health.detik.com/berita-detikhealth/d-5113898/negara-kaya-berlomba-borongvaksin-corona-bimana-nasib-dunia.

[19] Karel Vasak, "Human Rights: A Thirty-Year Struggle: the Sustained Efforts to give Force of law to the Universal Declaration of Human Rights", UNESCO Courier 30:11, P aris, November 1977, quoted as https: // Reference.elsam.or.id/wp-content/uploads/2014/12/K Kesehatan_Sebagai_Hak_Asasi_Manusia.pdf.

[20] Solikha, N. M. (2015). Asas Itikad Baik Sebagai Pembatas Kebebasan Berkontrak Dalam Perjanjian Kredit Bank, (Tesis: UII, Yogyakarta). 